\section{Systems of Pruning on Jigacho (Vasconcellea stipulata Badillo) under Greenhouse Conditions}

\author{
Borja Velázquez-Martí ${ }^{\mathbf{1}}$ \\ Departamento de Ingeniería Rural y Agroalimentaria, Universitat \\ Politècnica de València, Camino de Vera s/n, 46022 Valencia, Spain
}

Marco Castillo and Fidel Rodríguez

Facultad de Ciencias Agropecuarias, Universidad Técnica de Ambato, Campus Querochaca, cantón Cevallos, Tungurahua 18-01-334, Ecuador

Isabel López-Cortés

Departamento de Producción Vegetal, Universitat Politècnica de València, Camino de Vera s/n, 46022 Valencia, Spain

\section{Stefany Alcivar-Bastidas \\ Facultad de Ingeniería, Universidad Católica de Santiago de Guayaquil, Av. Carlos Julio Arosemena km. 1 1/2 Via Daule, Guayaquil, Ecuador}

Additional index words. Ecuador, Andes, toronche, Vasconcellea stipulata, underutilized fruits species, crop cycle, crop management system

\begin{abstract}
Vasconcellea stipulata Badillo is a fruit tree native of the temperate areas of the Andes valleys, found between 2000 and $2600 \mathrm{~m}$ above sea level. The good organoleptic qualities and few seeds of its fruit, compared with those of other Caricas, give it a high potential in markets. The development of this crop would allow the economic development of small-scale farmers and contribute to the preservation of genetic resources native to the Andean region. However, there are few studies concerning its appropriate cultivation. The aim of this study was to analyze the effect of different pruning techniques under greenhouse conditions. Trees were pruned to one, two, or three axes, or not pruned (control). The experiment was performed in a tunnel greenhouse with polyethylene cover, located $2950 \mathrm{~m}$ above sea level in Querochaca (Ecuador), with an annual rainfall of $465 \mathrm{~mm}$ and an average annual temperature of $12.9^{\circ} \mathrm{C}$. The duration of each stage of development was recorded. The number of flower clusters, number of flowers, production, incidence of diseases, and weight and size of fruit were recorded. Cuttings took over 90 days for getting before being transplanted into the greenhouse. Flowering began 283 days (40 weeks) after transplantation; fruit set began at 30 days after flowering (44 weeks after transplant); and the fruit started to mature 170 days after fruit set (69 weeks after transplant). The plants pruned to three axes had the greatest number of flowers and fruits and the greatest production, with an average 54 fruits per tree. Pruning had no effect on fruit dimensions.
\end{abstract}

Jigacho or toronche (Vasconcellea stipulata Badillo) is a fruit native to temperate areas of the Andes valleys, found between 2000 and $2600 \mathrm{~m}$ above sea level. This species is cultivated mainly in southern Ecuador and northern Peru (Badillo, 1993; Scheldeman et al., 2007). It is a semiwoody tree, which reaches $5-10 \mathrm{~m}$ height. It is characterized by spines (spiniform stipules) in the stem and leaf petiole. When leaves abscise, the petiole insertion produces large

Received for publication 27 Apr. 2017. Accepted for publication 22 May 2017.

The participation of Borja Velázquez Martí in this work was possible by the funding from the Ecuadorian Government through PROMETEO program, leaded by the Secretaría Nacional de Educación Superior, Ciencia y Tecnología (SENESCYT).

${ }^{1}$ Corresponding author. E-mail: borvemar@dmta. upv.es. scars on the stem (Kubitzki, 2003). Leaves are polylobed, pentagon-webbed, with a very high polymorphism (Fig. 1). They have an alternated arrangement forming a spiriform sequence. The plants have long pendular floral whorls, with female, male, and hermaphrodite flowers, differentiated by the androecium and gynoecium (Kubitzki, 2003). Flowers are yellow with reddish areas (Scheldeman et al., 2011). Fruits are small, $8-10-\mathrm{cm}$ long and $4-5-\mathrm{cm}$ wide, yellow, weighing between 40 and $150 \mathrm{~g}$. They have five lobes and grooves (6-10) that give a star shaped cross section, being pentacarpelar. The skin of the fruit is usually soft and easy to peel, its flesh is creamy, yellow, and smooth, with seven or 10 seeds.

Vasconcellea ssp. are trees grown not only for fruit consumption, but also as ornamental plants noted for the exquisite floral fragrance. Vasconcellea stipulate Badillo has been traditionally cultivated in domestic form on small plots, and its commercial development has been limited (Badillo, 1993; Scheldeman et al., 2002; Van den Eynden et al., 2003). Nevertheless, its good organoleptic qualities give it a high potential in the markets of Europe and North America where it is considered an exotic fruit (Baeza et al., 1990; Dhuique Mayer et al., 2001; Scheldeman et al., 2002). The fruit can be eaten fresh or processed industrially into jellies, jams, and juices, usually mixed with other fruits (Cossio, 1988). Its fruit is also interesting because of its high papain content (Kyndt et al., 2007; Misas-Villamil et al., 2016; Scheldeman et al., 2003), which is used in the pharmaceutical industry for the treatment of cancerous tumors and lymph, herniated discs, and abnormal formations that occur in the arteries (atherosclerosis). Papain is an anti-inflammatory agent in cases of infections and trauma (Aravind et al., 2013; Flindt, 1978; Kyndt et al., 2007). It is also used for healing ulcers in the digestive tract and in the treatment of dyspepsia and kidney dysfunction. It has industrial and cosmetic use in healing and eczema correction. In food industry, it is used as a meat tenderizers (Endt, 1983; Cossio, 1988).

The development of this crop would allow the economic development of small

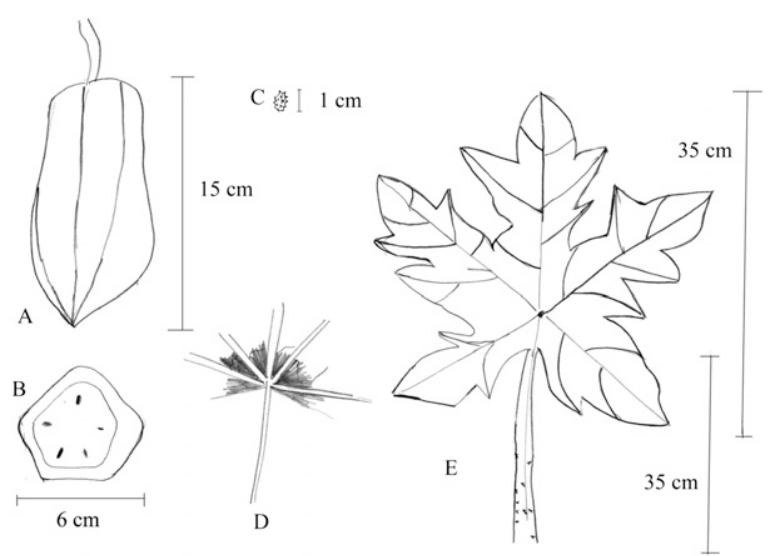

Fig. 1. Morphology of Jigacho (Vasconcellea stipulata V.M. Badillo) fruit and leaf. (A) Fruit; (B) transversal section of the fruit; (C) seed (D) abaxial connection of leaf-petiole; (E) leaf. 
farmers and contribute to the preservation of genetic resources originated in the Andean region. Its cultivation under greenhouse condition at high altitude is an opportunity to increase production under controlled conditions. However, there are few studies concerning proper cultural management. The aim of this study was to analyze the effect of different pruning techniques in the development of jigacho cultivated in a greenhouse. We studied their vegetative development and influence of pruning on the number of flowers, production, weight and size of fruits, as well as susceptibility to the most common diseases of this species.

\section{Materials and Methods}

Plant material. For the study, cuttings of jigacho stem (Vasconcellea stipulata Badillo) (Fig. 1) were taken from homogeneous adult plants $\approx 5$ years old, located in the cantons Salcedo and Cevallos (Ecuador). The length of the cuttings was $25-30 \mathrm{~cm}$ (3-4 internodes). The cuttings were kept for

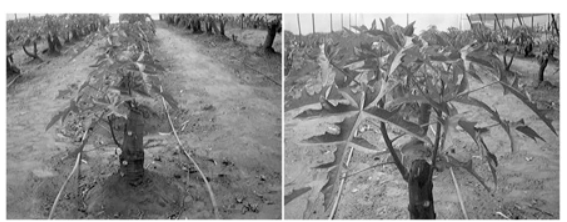

Fig. 2. View of jigacho planted in greenhouse: $\mathrm{S} 1$ (one axis) and S2 (two axes).

\begin{tabular}{|c|c|c|c|c|}
\hline S1 & S2 & S3 & C & S1 \\
\hline S2 & S3 & C & S1 & C \\
\hline S3 & C & S1 & S2 & S3 \\
\hline C & S1 & S2 & S3 & S2 \\
\hline
\end{tabular}

Fig. 3. Distribution of sampled plots in the greenhouse.
$11 \mathrm{~d}$ under shade, time in which part of the latex was eliminated and the cuts healed. After this time, the cuttings were placed on rooting medium for 3 months. The substrate was composed of $40 \%$ topsoil, $40 \%$ humus, $20 \%$ pomina. The cuttings were then planted in a greenhouse tunnel under polyethylene cover in sandy loam soil, irrigated by a drip system (Fig. 2). The greenhouse was located at the Experimental Farm of the Technical University of Ambato (Ecuador), located at $1^{\circ} 16^{\prime} 27.31^{\prime \prime}, 78^{\circ} 34^{\prime} 32.42^{\prime \prime}, X=-1,369,846 \mathrm{~m}$, $Y=-78,607,242 \mathrm{~m}$, at $2950 \mathrm{~m}$ above sea level. According to Querochaca Meteorological Station (2011-2014), the climate in this area is temperate, with $12{ }^{\circ} \mathrm{C}$ minimum temperature, $18{ }^{\circ} \mathrm{C}$ maximum temperature. The average temperature of $12.9^{\circ} \mathrm{C} ; 250 \mathrm{~mm}$ minimum and $600 \mathrm{~mm}$ maximum precipitation, the average annual precipitation was $465 \mathrm{~mm}$; relative humidity of $77 \%$; and a speed of wind of $4.2 \mathrm{~m} / \mathrm{s}$.

Experimental design. The experiment was conducted over 4 years. The most important approach to pruning jigacho is to define tree shape. This pruning approach determines the number of branches and its structure. After establishment, no significant changes are made in the structure of the plant. The effect of pruning was studied in this work, which can influence production. Four different types of pruning were studied: S1, the plant grew forming only one axis; S2, the plants were pruned forming two axes without branching; S3, the plants were pruned in three axes without branching; $C$, the plants had free growth. These treatments were randomly distributed in five blocks. Thus, 20 experimental plots were analyzed each year. In each block, a different type of pruning was performed in a plot. The distribution of the plot in the greenhouse is shown in Fig. 3. Each plot was composed of 12 plants. The plants were separated $1.5 \mathrm{~m}$ each on a row and the rows were $1.4 \mathrm{~m}$ distanced; therefore, each block occupied $25.2 \mathrm{~m}^{2}$.

The plants remained in the greenhouse for 4 years.

On each block, pruning was performed 3 months after the stakes were planted. Sub-

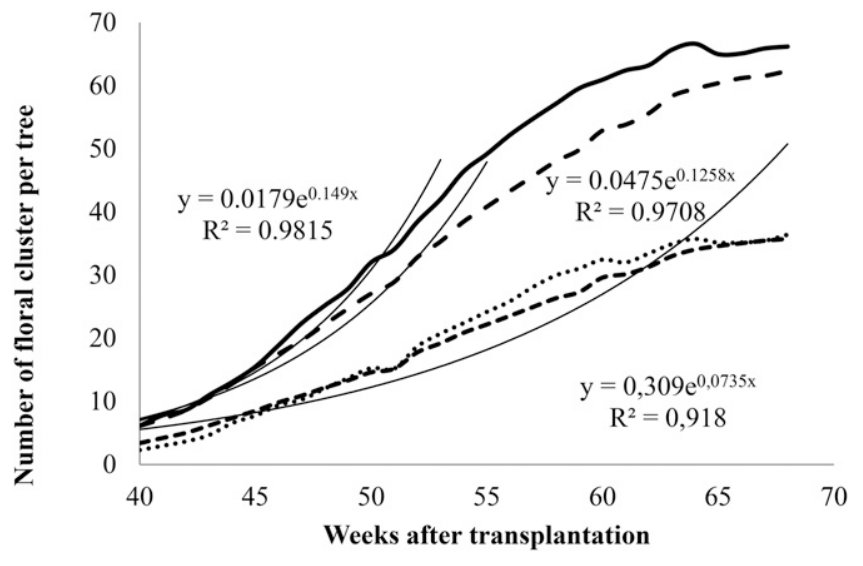

$---\mathrm{S} 3 \longrightarrow \mathrm{S} 2-\mathrm{S} 1 \cdots \cdots \mathrm{C}$

Fig. 4. Variation in the number of floral clusters in different types of pruning.

sequently, a continuous pruning was performed to remove unwanted shoots until the plant reached a year after sprouting.

Fertilizers were applied before planting with $100 \mathrm{~g} \cdot \mathrm{m}^{-2}$ triple superphosphate and $100 \mathrm{~g}$ muriate of potash $/ \mathrm{m}^{2}$. After planting, $26 \mathrm{~g}$ $\mathrm{N}, 50 \mathrm{~g} \mathrm{P}_{2} \mathrm{O}_{5}$ and $33 \mathrm{~g} \mathrm{~K}_{2} \mathrm{O} /$ plant were applied after 4, 7, and 10 months. Temperatures in the greenhouse average $21.0^{\circ} \mathrm{C}$, with $9.6{ }^{\circ} \mathrm{C}$ minimum and $33.4{ }^{\circ} \mathrm{C}$ maximum. The average relative humidity in the greenhouse was $57 \%$, with $26 \%$ minimum and $94 \%$ maximum.

To evaluate the effect of pruning, the following parameters were measured:

- Number of days to first flower

- Number of days to start fruiting

- Number of days to start harvest

- Number of fruits per plant

- Number of fruits per cluster

- Polar diameter of the fruit

- Equatorial diameter of fruit

- Soluble solids ( ${ }^{\circ}$ Brix)

- Average fruit weight

- Observation of the incidence of pests and diseases.

Comparison of pruning methods was performed using analysis of variance (ANOVA) with a confidence level of $95 \%$.

\section{Results and Discussion}

Analysis of the growth cycle. Figure 4 shows the variation in the average number of flower clusters in the trees with the different types of pruning during the weeks after transplant. Flowering began at $283 \mathrm{~d}$ after planting. The curves representing the variation of number of flower clusters vs. time were sigmoid. Flowering was initially slow; then, it increased exponentially between weeks 40 and 55 . The coefficients of determination of the exponential curves in those weeks vary between 0.97 and 0.98 for S1 and S2 treatment. The worse exponential curve represents the flowering process vs. time in the S3 and control treatment, which have no differences. These treatments produce a more lineal flowering process. Subsequently, increasing the bloom decreases until the number of flower clusters is constant. This model allows analyzing differences between treatments and predicting the production with few weeks of the cycle because the number of flowers and fruit is proportional. These equations are not lineal probably because of liberation of the hormones to flowering are progressive. Table 1 shows the means and standard deviations of the number of clusters at the end of each month. Analysis of variance was performed to determine if there are differences between the numbers of floral clusters in different types of pruning with $95 \%$ of confidence level, the number of flowers per plant with time, number of fruits per tree with time, number of drop fruits over time.

The number of flower clusters per plant formed at 283 and $313 \mathrm{~d}$ showed narrow 
Table 1. Average and SD of evaluated parameters according to the time after transplantation (sample 48 plants, 12 per year). Treatments - S1: plants were growing forming only one axis; S2: plants were pruned forming two axes without branching; S3: plants were pruned in three axes without branching; C: plants had free growth. Analysis of variance at $95 \%$ confidence level.

\begin{tabular}{|c|c|c|c|c|c|c|c|c|}
\hline & Week 40 & Week 44 & Week 48 & Week 52 & Week 56 & Week 60 & Week 64 & Week 68 \\
\hline & $283 \mathrm{~d}$ & $313 \mathrm{~d}$ & $343 \mathrm{~d}$ & $373 \mathrm{~d}$ & $403 \mathrm{~d}$ & $433 \mathrm{~d}$ & $463 \mathrm{~d}$ & $493 \mathrm{~d}$ \\
\hline \multicolumn{9}{|c|}{ Number of floral clusters per plant } \\
\hline $\mathrm{S} 1$ & $6.11 \pm 2.30 \mathrm{a}$ & $12.79 \pm 3.33 \mathrm{a}$ & $22.19 \pm 4.85 \mathrm{a}$ & $32.83 \pm 5.52 \mathrm{a}$ & $43.30 \pm 6.78 \mathrm{a}$ & $52.90 \pm 9.02 \mathrm{a}$ & $59.50 \pm 19.27 \mathrm{a}$ & $62.35 \pm 15.28 \mathrm{a}$ \\
\hline $\mathrm{S} 2$ & $6.13 \pm 4.45 \mathrm{a}$ & $13.08 \pm 8.04 \mathrm{a}$ & $25.18 \pm 8.37 \mathrm{a}$ & $38.45 \pm 7.61 \mathrm{a}$ & $52.20 \pm 8.83 \mathrm{a}$ & $60.95 \pm 5.66 \mathrm{a}$ & $66.65 \pm 12.18 \mathrm{a}$ & $66.20 \pm 16.47 \mathrm{a}$ \\
\hline S3 & $3.39 \pm 2.00 \mathrm{~b}$ & $7.36 \pm 3.35 \mathrm{~b}$ & $12.17 \pm 4.48 \mathrm{~b}$ & $17.78 \pm 6.26 b$ & $23.55 \pm 7.43 b$ & $29.60 \pm 8.76 b$ & $34.05 \pm 6.68 \mathrm{~b}$ & $35.75 \pm 14.99 b$ \\
\hline $\mathrm{C}$ & $2.29 \pm 2.83 \mathrm{~b}$ & $6.57 \pm 5.86 \mathrm{~b}$ & $12.04 \pm 8.49 b$ & $18.70 \pm 11.38 \mathrm{~b}$ & $25.85 \pm 14.25 b$ & $32.45 \pm 17.18 b$ & $35.73 \pm 11.49 b$ & $36.40 \pm 11.28 \mathrm{~b}$ \\
\hline \multicolumn{9}{|c|}{ Number of flowers per plant } \\
\hline $\mathrm{S} 1$ & $6.76 \pm 2.54 \mathrm{a}$ & $14.11 \pm 5.88 \mathrm{a}$ & $30.96 \pm 10.04 \mathrm{a}$ & $31.63 \pm 9.81 \mathrm{a}$ & $42.10 \pm 9.19 b$ & $50.50 \pm 12.47 \mathrm{a}$ & $44.50 \pm 9.81 \mathrm{a}$ & $33.95 \pm 10.16 \mathrm{a}$ \\
\hline $\mathrm{S} 2$ & $6.96 \pm 5.12 \mathrm{a}$ & $13.62 \pm 8.88 \mathrm{a}$ & $31.65 \pm 15.14 \mathrm{a}$ & $38.53 \pm 11.46 \mathrm{a}$ & $58.42 \pm 9.97 \mathrm{a}$ & $66.55 \pm 8.97 \mathrm{a}$ & $56.3 \pm 10.79 \mathrm{a}$ & $36.95 \pm 8.85 \mathrm{a}$ \\
\hline S3 & $4.35 \pm 3.04 \mathrm{a}$ & $9.07 \pm 5.15 \mathrm{a}$ & $17.83 \pm 9.59 \mathrm{ab}$ & $17.95 \pm 9.64 b$ & $24.64 \pm 8.90 \mathrm{c}$ & $26.35 \pm 8.94 \mathrm{c}$ & $28.4 \pm 10.04 b$ & $22.70 \pm 13.40 b$ \\
\hline $\mathrm{C}$ & $2.55 \pm 2.93 \mathrm{a}$ & $6.47 \pm 5.96 \mathrm{a}$ & $13.46 \pm 9.42 \mathrm{~b}$ & $14.82 \pm 8.07 b$ & $26.20 \pm 12.75 \mathrm{c}$ & $30.05 \pm 11.43 \mathrm{c}$ & $28.25 \pm 12.00 \mathrm{~b}$ & $18.72 \pm 7.71 b$ \\
\hline \multicolumn{9}{|c|}{ Number of fruits per plant } \\
\hline $\mathrm{S} 1$ & $0.00 \pm .0 .00 \mathrm{a}$ & $1.61 \pm 1.03 \mathrm{a}$ & $5.19 \pm 2.79 \mathrm{a}$ & $23.33 \pm 9.81 \mathrm{a}$ & $36.25 \pm 9.10 \mathrm{a}$ & $44.50 \pm 12.45 \mathrm{a}$ & $52.6 \pm 17.75 \mathrm{a}$ & $55.20 \pm 23.05 \mathrm{a}$ \\
\hline $\mathrm{S} 2$ & $0.19 \pm 0.42 \mathrm{a}$ & $1.64 \pm 1.75 \mathrm{a}$ & $4.99 \pm 3.01 \mathrm{a}$ & $24.13 \pm 11.46 \mathrm{a}$ & $33.93 \pm 11.15 \mathrm{a}$ & $40.20 \pm 7.64 \mathrm{a}$ & $45.2 \pm 7.56 \mathrm{a}$ & $49.45 \pm 7.13 \mathrm{a}$ \\
\hline $\mathrm{S} 3$ & $0.05 \pm 0.11 \mathrm{a}$ & $1.02 \pm 0.89 \mathrm{a}$ & $4.39 \pm 1.94 \mathrm{a}$ & $17.52 \pm 9.64 \mathrm{a}$ & $25.40 \pm 12.32 \mathrm{a}$ & $33.00 \pm 17.94 \mathrm{a}$ & $38.35 \pm 21.80 \mathrm{a}$ & $40.50 \pm 8.42 b$ \\
\hline $\mathrm{C}$ & $0.00 \pm 0.00 \mathrm{a}$ & $0.41 \pm 0.52 \mathrm{a}$ & $3.04 \pm 3.57 \mathrm{a}$ & $12.55 \pm 10.52 \mathrm{a}$ & $17.08 \pm 13.63 \mathrm{a}$ & $23.1 \pm 7.09 \mathrm{~b}$ & $27.90 \pm 21.04 \mathrm{a}$ & $31.96 \pm 10.74 b$ \\
\hline \multicolumn{9}{|c|}{ Number of drop fruit } \\
\hline $\mathrm{S} 1$ & - & - & - & $0.83 \pm 0.73 \mathrm{ab}$ & $1.08 \pm 0.56 \mathrm{ab}$ & $7.65 \pm 3.99 \mathrm{ab}$ & $3.60 \pm 2.27 \mathrm{~b}$ & $2.35 \pm 0.80 \mathrm{~b}$ \\
\hline $\mathrm{S} 2$ & - & - & - & $1.23 \pm 0.32 \mathrm{a}$ & $1.45 \pm 0.60 \mathrm{a}$ & $11.08 \pm 4.64 \mathrm{a}$ & $6.70 \pm 1.57 \mathrm{a}$ & $4.25 \pm 1.31 \mathrm{a}$ \\
\hline $\mathrm{S} 3$ & - & - & - & $0.30 \pm 0.29 b$ & $0.53 \pm 0.37 b$ & $4.20 \pm 2.21 \mathrm{~b}$ & $1.50 \pm 0.50 \mathrm{c}$ & $1.15 \pm 0.57 \mathrm{~b}$ \\
\hline $\mathrm{C}$ & - & - & - & $0.60 \pm 0.35 \mathrm{ab}$ & $0.70 \pm 0.47 \mathrm{~b}$ & $7.25 \pm 3.64 \mathrm{ab}$ & $2.89 \pm 1.07 \mathrm{bc}$ & $2.16 \pm 1.06 \mathrm{~b}$ \\
\hline
\end{tabular}

differences in the types of pruning applied. This means that the four systems had small different responses to the formation of flower clusters. However, by the 48th week after transplant, the plants pruned to S1 and S2 (principal axes 1 and 2) had statistically more flowers than S3 treatment (main axis) and control (free growth). The average number of flowers in S1 and S2 treatments reached 64.5 per plant; however, in S3 and control treatments, it reached only 36.3 flower clusters per plant.

Figure 5 shows the variation in the number of flowers per plant vs. time, and in Table 1 is shown the ANOVA carried out to evaluate the differences between the treatments. Again it is shown that treatments $\mathrm{S} 1$ and S2 have provided more flowers per plant. Of course, this is related with the number of clusters. The greatest number of flowers was obtained at 60 th week. The trees with more flowers are those who had undergone the S2 treatment with an average of 66.55 flowers per plant. At the 54th and 64 th week, the number of flowers decreased, because of floral abscission and development of fruit.

Figure 6 shows the number of fruit in the trees for each type of pruning. It can be seen that the number of fruits per tree grew exponentially between the 44th and 55 th week. From week 55, the number of fruits decreased because of the increase in fruit drop (Fig. 7). The types of pruning with more fruits were S1 and S2, with 53 fruits average at 69 th week after transplantation. These treatments differed significantly from S3 and control treatments, which had a mean of 38 fruits per tree, although pruning types $\mathrm{S} 1$ and S2 are also where there was more fruit drop.

The fruit reached the proper maturity for harvest at 69 th week after transplant. The fruit were collected with average size of $6.1 \mathrm{~cm}$ diameter and $16.5 \mathrm{~cm}$ long, occu-

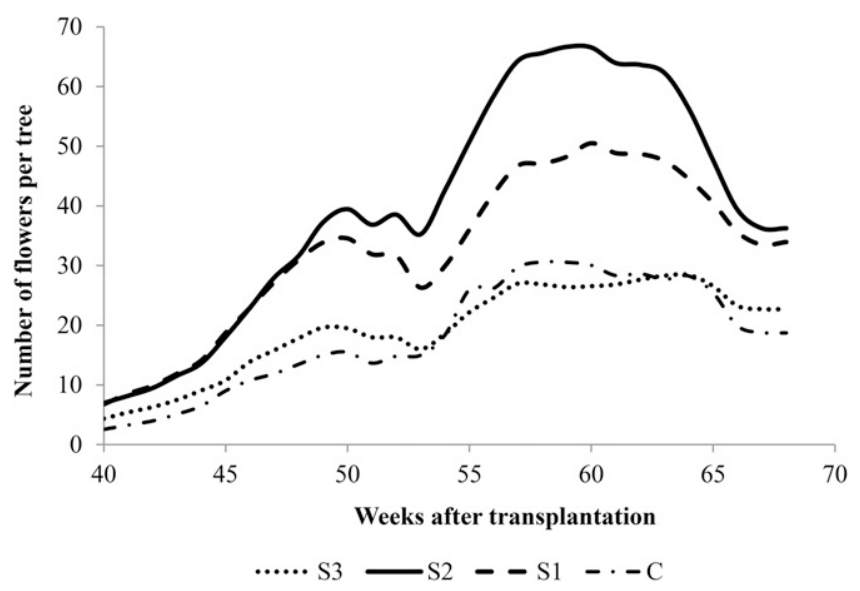

Fig. 5. Variation in the number of flowers per plant with time (sample 60 plants, 12 per block).

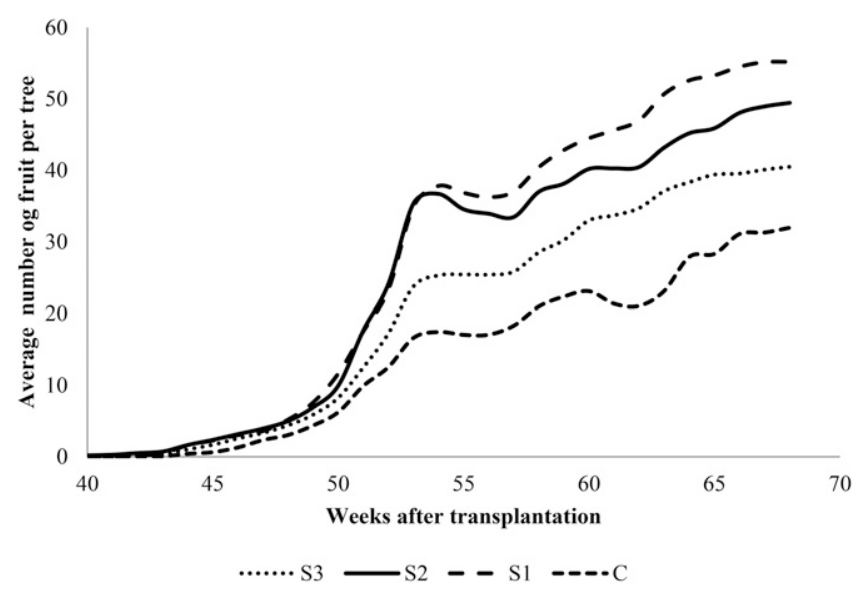

Fig. 6. Variation of the number of fruits per tree with time (sample 60 plants, 12 per block).

pying a volume of $28.2 \mathrm{~cm}^{3}$, and average weight was $290 \mathrm{~g}$, with a $\mathrm{pH} 4.49$ and a juice with $9.79^{\circ}$ Brix. No significant differences existed in the properties of the fruit between the different treatments of tested pruning. The size and weight in the fruit grown in the greenhouse conditions were higher than those reported by Badillo (1993).

According to the analysis presented, the cycle followed the next pattern (Fig. 8): $90 \mathrm{~d}$ 


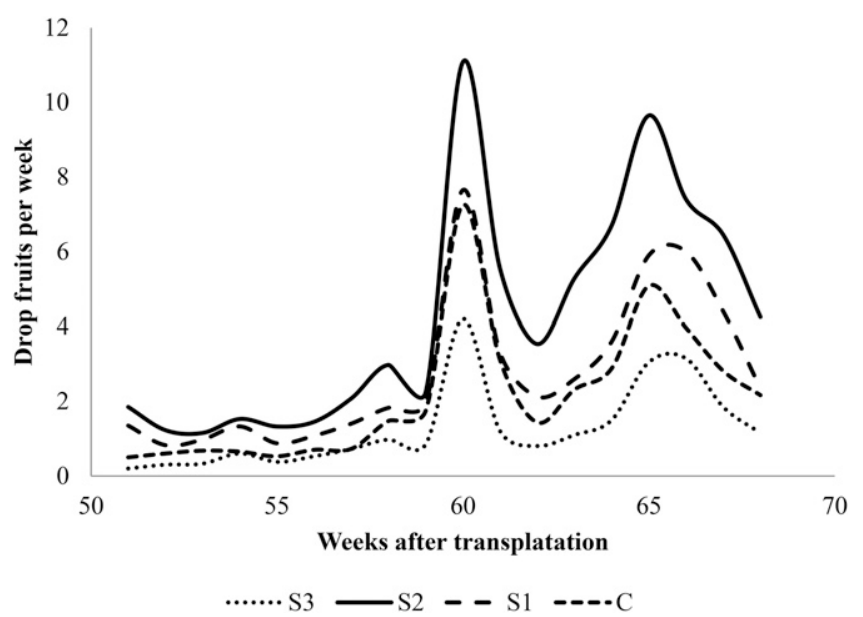

Fig. 7. Variation of the number of drop fruits over time (sample 60 plants, 12 per block).

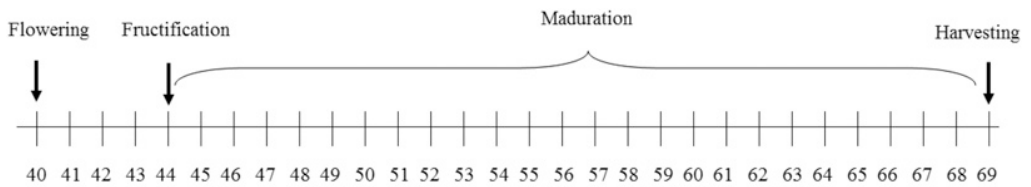

Weeks after trasplantation

Fig. 8. Cycle of Vasconcellea stipulata Badillo.

Table 2. Properties of the harvested fruits (sample 400 fruits, 100 per year).

\begin{tabular}{lc}
\hline & $\bar{x} \pm \sigma$ \\
\hline Equatorial diameter $(\mathrm{cm})$ & $6.1 \pm 0.6$ \\
Length $(\mathrm{cm})$ & $16.1 \pm 1.2$ \\
Volume $\left(\mathrm{cm}^{3}\right)$ & $282.2 \pm 46.7$ \\
Weight $(\mathrm{g})$ & $289.5 \pm 47.8$ \\
Juice $\mathrm{pH}$ & $4.51 \pm 0.7$ \\
Soluble solids of the juice $\left({ }^{\circ}\right.$ Brix $)$ & $9.97 \pm 0.42$ \\
\hline
\end{tabular}

were spent for rooting and transplanting of stem cuttings. After transplantation, the flowering began at $283 \mathrm{~d}$ ( 40 th week), fruit setting started at $30 \mathrm{~d}$ after flowering (44 weeks after transplantation). The maturation time of the fruit from the fructification to harvest was $170 \mathrm{~d}$, performing the harvesting at 69 weeks after transplantation. Table 2 shows mean and standard deviation of the parameters of the harvested fruits.

Diseases observed in the crop. A small infection of root rot was observed, which was attributed to the presence of Fusarium spp. It was found at the level of the crown that the color of the tissues turned lightly brown, and as the disease progressed, it became watery. The leaves turned chlorotic, being withered until they fall, and also the fruit, until finally the entire plant died.

Another significant infection was incited by the presence of mildew on the underside of leaves with chlorotic spots in the beam, which enlarge and grouped, the photosynthetic area of the plant being notably reduced. This probably occurred by the presence of oidium. The attack became more severe in low relative humidity (Vivas et al., 2016).
At the 10th month after planting, the presence of "brown leaf spot" was also detected. This was probably incited by fungus Asperisporium spp. This is a little parasite known by its specific attacks to the Caricaceae family, causing small necrotic spots $(0.2-0.8 \mathrm{~cm}$ in diameter) in the leaves' bundle. Under the leaf, there are also small necrotic spots randomly distributed.

Differences of disease affectation were not observed between the studied pruning systems.

Comparison with papaya. No previous publication has reported on the pruning of Vasconcellea spp., although they are very proximate to Caricaceae. The most studied Carica species has been the pawpaw tree (Carica papaya L.). Niklas and Thomas (2007) studied the effects of its domestication on vegetative growth of this crop, but this is a Caricaceae, cultivated in warm weather. Barros et al. (2009) studied the effect of pruning at different heights of the trunk in the papaya cv. Golden, with two and half years old, during the productive period. The treatments consisted of pruning at five heights $(0.5,1.0,1.5,2.0 \mathrm{~m}$ starting from the ground, and complete without the apex). Evaluated characteristics were number of shoots at 25 and $50 \mathrm{~d}$ after the pruning, length of the sprouts longer than $5 \mathrm{~cm}$ at $50 \mathrm{~d}$ after the pruning, and distribution of the shoots in trunk height at $50 \mathrm{~d}$. These works demonstrated that Caricaceae production is influenced by pruning, whereas the different types of pruning were shown not to change the fruit quality. Such finding has been verified in the present study, where pruning S1 and S2 improved the fruit yield of jigacho.
Kumar et al. (2014), studied the effects of tree spacing $(5 \times 2 \mathrm{~m}, 5 \times 2.5 \mathrm{~m}, 5 \times 3 \mathrm{~m}, 5 \times$ $3.5 \mathrm{~m}$, and $5 \times 4 \mathrm{~m}$ ) and pruning (eight buds/ cane, six buds/cane, and four buds/cane) on vegetative growth, physiological parameters, fruit yield, and quality were studied in fig (Ficus carica L.) cv. Deanna in the third and fourth year of its growth during the period 2010-12. They observed that with increase in tree spacing, growth parameters such as leaf number, shoot length, internode length, treespread, tree height, and tree circumference, along with fruit yield both in terms of fruit number and fruit weight per tree, declined gradually under different pruning levels. Increase in pruning level from eight buds/ cane to four buds/cane resulted in increased leaf number, shoot length and internode length. Yield characters, viz., fruit number/ tree, fruit weight/tree, fruit number/hectare, and fruit weight/hectare were marginally influenced by pruning. However, interaction effects of pruning and spacing were found to be nonsignificant. Effects of spacing were more conspicuous than those of pruning. Best results for maintenance of vigor and fruit yield were observed under a spacing of $5 \times$ $2 \mathrm{~m}$ or $5 \times 2.5 \mathrm{~m}$, and four buds/cane pruning. Although there was reduction in average fruit size under closer spacing when compared with wide spacing, fruit quality attributes such as total soluble solids and acidity were unaffected by various treatments. Effects of closer spacing on growth and yield parameters were more pronounced in the third year as compared with the fourth year, showing better response to treatments in young trees.

\section{Conclusions}

Cycle of Vasconcellea stipulata Badillo cultivated in cold Andinean areas under greenhouse without additional heat system has been described. It was found that flowering in jigacho begins in at week 40 after transplantation. The fructification begins at week 44 after transplanting. The maturation time of the fruit is of $170 \mathrm{~d}$, being harvested from week 69 after transplantation.

In this article, three types of pruning were assessed, comparing with the free growth. It has been shown that plant configurations in one and two axes provide a higher production than free development or the growing with three axes. This may be because nutrients are better distributed and differentiation hormone act more efficiently. When the plant has free growing and the number of branches is high, the flower number of available flowers is reduced, and excess flowers make them less viable.

The fruits obtained in trees under greenhouse are larger and heavier than those obtained outdoors. The different types of pruning did not influence the size and weight of the fruit. The disease infections in the greenhouse cultivation are acceptable for large-scale production.

This article demonstrates that cultivation of jigacho can be carried out under 
greenhouse with an acceptable yield of 38 fruits per tree, about $11 \mathrm{~kg}$.

\section{Literature Cited}

Aravind, G., D. Bhowmik, S. Duraivel, and G. Harish. 2013. Health benefits and medicinal properties of Carica papaya. Ann. Plant Sci. 2(2):1-27.

Badillo, V.M. 1993. Caricaceae. Segundo esquema. Rev. Fac. Agron. Univ. Cent. Venez. 43:1-111.

Baeza, G., D. Correa, and C. Salas. 1990. Proteolytic enzymes in Carica candamarcensis. J. Sci. Food Agr. 51:1-9.

Barros, F.L.D., E.R. Schmildt, J.A.T. do Amaral, and R.I. Coelho. 2009. Influence of the pruning to different heights in papaya tree 'Golden'. Rev. Ciênc. Agron. 40(4):596-601.

Cossio, F. 1988. Il Babaco. Edagricoles, Bologna, Italy.

Dhuique Mayer, C., Y. Caro, M. Pina, J. Ruales, M. Dornier, and J. Graille. 2001. Biocatalytic properties of lipase in crude latex from babaco fruit (Carica pentagona). Biotechnol. Lett. 23 (13):1021-1024

Endt, D.J.W. 1983. Where the babaco began. Southern Hort. 13:24-26.

Flindt, M.L.H. 1978. Respiratory hazards from papain. Lancet 311(8061):430-432.
Kubitzki, K. 2003. Caricaceae. Flowering plants.dicotyledons. The families and genera of vascular plants. Vol. 5, Springer, p. 57-61.

Kumar, R., S. Ganesh, R. Chithiraichelvan, K.K. Upreti, and V.V. Sulladmath. 2014. Effect of spacing and pruning on growth, yield and quality of cv. Deanna fig (Ficus carica L.). J. Hort. Sci. 9(1):31-37.

Kyndt, T., J.M. Van Damme Els, J. Van Beeumen, and G. Gheysen. 2007. Purification and characterization of the cysteine proteinases in the latex of Vasconcellea spp. FEBS J. 274(2):301-574.

Misas-Villamil, J.C., R.A.L. van der Hoorn, and G. Doehlemann. 2016. Papain-like cysteine proteases as hubs in plant immunity. New Phytol. 212:902-907.

Niklas, K.J. and E.M. Thomas. 2007. Carica papaya (Caricaceae): A case study into the effects of domestication on plant vegetative growth and reproduction. Amer. J. Bot. 94 (6):999-1002.

Scheldeman, X., T. Kyndt, G. Coppens d'Eeckenbrugge, R. Ming, R. Drew, and P. Van Damme. 2011. C. Kole (ed.). Wild crop relatives: Genomic and breeding resources: Tropical and subtropical fruits. Springer, Heidelberg, Germany.

Scheldeman, X., P. Van Damme, J. Alvarez, and J. Romero Motoche. 2003. Horticultural potential of Andean fruit crops exploring their centre of origin. Proc. Intl. Symp. on Sustainable Use of Plant Biodiversity to Promote New Opportunities for Hort. Production Dev. Intl. Soc. Hort. Sci., The Hague, The Netherlands. p. $97-102$.

Scheldeman, X., P. Van Damme, and J. Romero Motoche. 2002. Highland papayas in southern Ecuador: Need for conservation actions. Acta Hort. 575(1):199-205.

Scheldeman, X., L. Willemen, G. Coppens d'Eeckenbrugge, E. Romeijn-Peeters, M.T. Restrepo, J. Romero Motoche, D. Jiménez, M. Lobo, C.I. Medina, C. Reyes, D. Rodríguez, J.A. Ocampo, P. Van Damme, and P. Goetgebeur. 2007. Distribution, diversity and environmental adaptation of highland papayas (Vasconcellea spp.) in tropical and subtropical America. Biodivers. Conserv. 16:1867-1884.

Van den Eynden, V., E. Cueva, and O. Cabrera. 2003. Wild foods from Ecuador. Econ. Bot. 57 (4):576-603.

Vivas, M., H.C.C. Ramos, P.H.D. Santos, S.F. Silveira, T.N.S. Pereira, A. Teixeira do Amaral, Jr., and M.G. Pereira. 2016. Heterosis and genetic diversity for selection of papaya hybrids for resistance to black spot and phoma spot. Trop. Plant Pathol. 41:380 389. 